\title{
Solar sterilization of abscised fruit: A cultural practice to reduce infestations of Anastrepha obliqua around orchards $\mathbf{s}^{1,2}$
}

\author{
David A. Jenkins ${ }^{3}$, Edgardo Día ${ }^{4}$, Daniel M. Jenkins ${ }^{5}$, \\ and Ricardo Goenaga ${ }^{6}$
}

J. Agric. Univ. P.R. 92(3-4):197-206 (2008)

\begin{abstract}
Abscised mangoes, Mangifera indica, of several cultivars were stored under varying conditions: no sun (stored in a laboratory), shade (stored under the shade of a mango tree), full sun (stored in direct view of the sun), and covered with a black plastic bag and stored in direct view of the sun. The numbers of living Anastrepha obliqua larvae emerging from each treatment were compared and internal temperatures of the mangoes in the various storage regimes recorded. Mangoes stored in the laboratory almost always produced more larvae than mangoes stored under the other regimes, even though internal temperatures of mangoes stored in shade were not much higher than those of mangoes stored in the laboratory. Internal temperatures of mangoes stored under black plastic garbage bags in full sun consistently reached temperatures fatal to $A$. obliqua and other Tephritidae. Nonetheless, mortality was not consistently higher in these treatments than in the treatments stored in the shade. We suspect that cloudy weather reduced the internal temperatures of the mangoes to sufficiently tolerable levels for larval survival. Removing abscised mangoes from the shade of the tree may reduce infestations on the arid side of the island, where sunny days are more common. Our research suggests that removing abscised fruit from the shade of backyard trees, along with other strategies, may be useful in establishing a fruit flyfree zone.
\end{abstract}

Key words: mango, fruit flies

\section{RESUMEN}

Esterilización solar de fruta caída: Práctica cultural para reducir la infestación de Anastrepha obliqua en los huertos

${ }^{1}$ Manuscript submitted to Editorial Board 4 April 2008.

${ }^{2}$ The authors wish to thank Martex Farms for providing mangoes and Elkin Vargas for his excellent field work.

${ }^{3}$ USDA-ARS Tropical Agriculture Research Station, 2200 Ave. P.A. Campos, Ste. 201, Mayaguez, PR, 00680-5470. Corresponding author David.Jenkins@ars.usda.gov.

${ }^{4}$ Department of Horticulture, University of Puerto Rico, Mayaguez, PR.

${ }^{5}$ Department of Molecular Biosciences and Bioengineering, University of Hawaii, Manoa, Honolulu, HI.

${ }^{6}$ USDA-ARS Tropical Agriculture Research Station. 
Frutas de mango de varias variedades se recogieron del suelo y se almacenaron bajo varias condiciones: sin recibir luz solar (almacenadas en el laboratorio), sombra (almacenadas bajo la sombra de un árbol de mango), bajo el sol, y bajo una bolsa plástica negra a pleno sol. Se comparó el número de larvas vivas de Anastrepha obliqua emergiendo de las frutas en cada tratamiento. La temperatura interna de las frutas en cada tratamiento se monitoreó durante el periodo experimental. Las frutas de mango almacenadas en el laboratorio produjeron más larvas que aquellas en otros tratamientos, aun cuando la temperatura interna de las frutas almacenadas en sombra no fue mucho más alta que la de las frutas almacenadas en el laboratorio. En días claros, las frutas almacenadas al sol, y aquellas bajo bolsas plásticas negras a pleno sol consistentemente alcanzaron temperaturas que fueron letales para las larvas de varias especies de mosca frutera Tephritidae. Sin embargo, la mortandad no fue mayor en estos tratamientos que en los tratamientos donde la fruta se almacenó bajo sombra. Sospechamos que en días nublados la temperatura interna en las frutas se reduce a niveles que las larvas Tephritidae pueden tolerar. En la costa sur de Puerto Rico, donde ocurre la mayor producción de mango y donde hay menos días nublados, el remover frutas de la sombra podría reducir la infestación de larva de mosca de frutas en los alrededores de los huertos.

Palabras clave: mango, mosca frutera

\section{INTRODUCTION}

The internal conditions of a fruit host, including oxygen content and temperature, play a significant role in the survival of insects infesting it. Guava fruit, Psidium guajava L. (Myrtaceae), coated with waxes or other materials typically had higher carbon dioxide and lower oxygen levels. In coated guavas the number of surviving Anastrepha suspensa (Loew) (Diptera: Tephritidae) larvae was reduced to $9 \%$ to $68 \%$ of the number of larvae surviving in uncoated fruits (Hallman et al., 1995).

Heat is often used to kill insects infesting fruit before it is exported to markets that restrict the importation of fruit from areas with endemic pest populations. Disinfestation of mangoes containing pupae of A. suspensa is often achieved by immersion in hot water (Sharp et al., 1989; APHIS, 1989) or steam (APHIS, 1985). High temperatures can interfere with protein production (Tomasovic and Koval, 1985) and disrupt cellular transcription, processing and translocation (Denlinger et al., 1990).

Mangoes are widespread on the island and are an important host of A. obliqua Marquart (Jenkins and Goenaga, 2008). Naturalized mangoes and mangoes in yards are key sources of infestations in commercial fruit crops. If infestations in mangoes could be curbed, commercial fruit production would benefit. Solar energy is a bountiful resource in tropical regions of the world, including the Caribbean. We hypothesized that solar energy could be used to raise the internal temperature of mangoes infested with $A$. obliqua. 


\section{MATERIALS AND METHODS}

Abscised mangoes were collected from the ground and distributed equally among plastic bins $(60 \times 41 \times 26 \mathrm{~cm}$, United States Plastic Corp., Lima, $\mathrm{OH})^{7}$ containing enough vermiculite to fill the bin to a depth of $5 \mathrm{~cm}$. The plastic bins with mangoes and vermiculite were stored under one of the following conditions for three days: shaded (either under a tree or, in the case of the trial with cv. Winters in 2005, under shade cloth); in a laboratory $\left(25^{\circ} \mathrm{C}\right.$ and $\left.50 \% \mathrm{RH}\right)$; in full sun; or covered with a black plastic garbage bag (114 1, ULINE, Waukegan, IL) and placed in full sun. There was an additional treatment for cv. Winters: covered with the plastic garbage bag and placed in the shade. There were five bins per treatment. In 2005, the experiment was conducted with the following mangoes cultivars: Winters, obtained from the USDA-ARS Agricultural Experiment Station in Isabela, Puerto Rico (fruit collected 29 July, with 10 fruits per bin); Palmer, obtained from the USDA-ARS Tropical Agriculture Research Station in Mayagüez, Puerto Rico (fruit collected 2 August, with seven fruits per bin); an unidentified mango cultivar, also obtained from the USDA-ARS Tropical Agriculture Research Station in Mayagüez, Puerto Rico (fruit collected 3 August, with seven fruits per bin); and Keitt, obtained from Martex Farms, Santa Isabel, Puerto Rico (fruit collected 15 August, with 10 fruits per bin). Because there were not enough fruit of the unidentified mango cultivar to distribute them among the four above described treatments, these mangoes were not subjected to the sun treatment.

In 2006, the experiment was conducted with mangoes cv. Winters obtained from the USDA-ARS Agricultural Experiment Station in Isabela, Puerto Rico (fruit collected 19 June, with five fruits per bin), and with mangoes cv. Mayagüezano collected from the USDA-ARS Tropical Agriculture Research Station in Mayagüez, Puerto Rico (fruit collected 3 August, with 10 fruits per bin).

The ambient temperatures and the temperatures inside the mangoes were recorded by using a thermocouple at various times of the day for the duration of the experiment. The thermocouple was placed next to the seed. None of the mangoes used in these trials received pesticide applications.

After storage under the described conditions for three days, all mangoes were moved to the laboratory and monitored daily for one week for

${ }^{7}$ Company and trade names in this publication are used only to provide specific information. Mention of a company or trade name does not constitute a warranty of equipment or materials by the Agricultural Experiment Station of the University of Puerto Rico, nor is this mention a statement of preference over other equipment or materials. 
the emergence of living larvae and pupae. Larvae and pupae were placed in plastic petri dishes with moistened vermiculite and stored at $25^{\circ} \mathrm{C}$ and $65 \% \mathrm{RH}$. The petri dishes were monitored daily for the emergence of adult fruit flies.

The mean number of larvae collected per fruit in each treatment were compared using an analysis of variance (ANOVA), with a StudentNeuman-Keuls means separation test (alpha $=0.05$ ) for significant differences encountered in the ANOVA.

\section{RESULTS}

Mangoes stored under laboratory conditions almost always produced significantly more larvae than mangoes stored outdoors (Figures 1 and 2). The only case for which this observation was not true was for the trials conducted on the Palmer cultivar, which produced too few larvae for meaningful statistical analysis (Figure 1). In five out of six trials the mean number of larvae produced in the treatments covered with a black plastic bag did not differ significantly from the mean number of larvae produced by fruit stored in full sun, and in four out of six trials the mean number of larvae produced by fruit stored under a black plastic bag in full sun did not differ significantly from the mean number of larvae produced by mangoes stored in the shade (Figures 1 and 2).

Internal temperatures of mangoes stored uncovered in the sun, as well as those in black garbage bags with exposure to the sun, peaked at 52 and $59^{\circ} \mathrm{C}$, respectively (Figure 3 ). However, on cloudy days the internal temperatures of mangoes stored in the sun and in black garbage bags with exposure to the sun peaked only at approximately $50^{\circ} \mathrm{C}$. The internal temperatures of mangoes stored in the shade peaked at $37^{\circ} \mathrm{C}$ (Figure 3).

\section{DISCUSSION}

Much work has been conducted to establish effective means of treating fruit so that very little chance exists for these fruits to contain living insect larvae that may establish populations at their export destinations. Exposing mango fruit infested with larvae of $A$. suspensa to hot air $\left(48^{\circ} \mathrm{C}\right)$ for $136.7 \mathrm{~min}$ achieved probit 9 mortality $(99.9968 \%$ mortality) (Sharp, 1992). Mangoes thus exposed had a core fruit temperature of $46^{\circ} \mathrm{C}$. Exposing mangoes infested with A. obliqua to hot air $\left(48.1^{\circ} \mathrm{C}\right)$ until the core fruit temperature was $48^{\circ} \mathrm{C}$ resulted in probit 9 mortality (Mangan and Ingle, 1992). Exposing carambola fruit, Averrhoa carambola $\mathrm{L}$. (Oxalidaceae), to air heated to $47^{\circ} \mathrm{C}$ for one hour resulted in $100 \%$ mortality of $A$. suspensa larvae infesting this fruit 
J. Agric. Univ. P.R. vOL. 92, NO. 3-4, JULY-OCTOBER 2008201

Winters

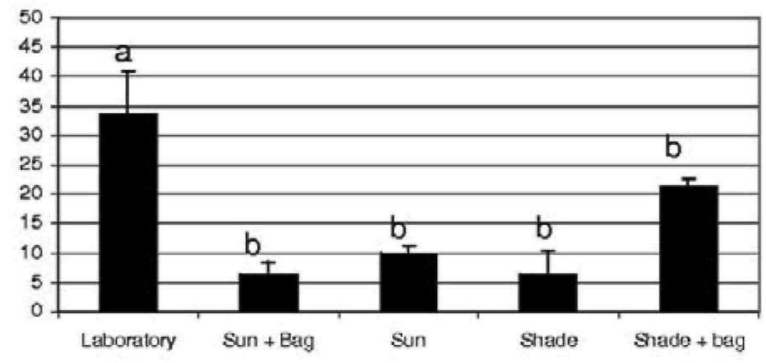

Palmer

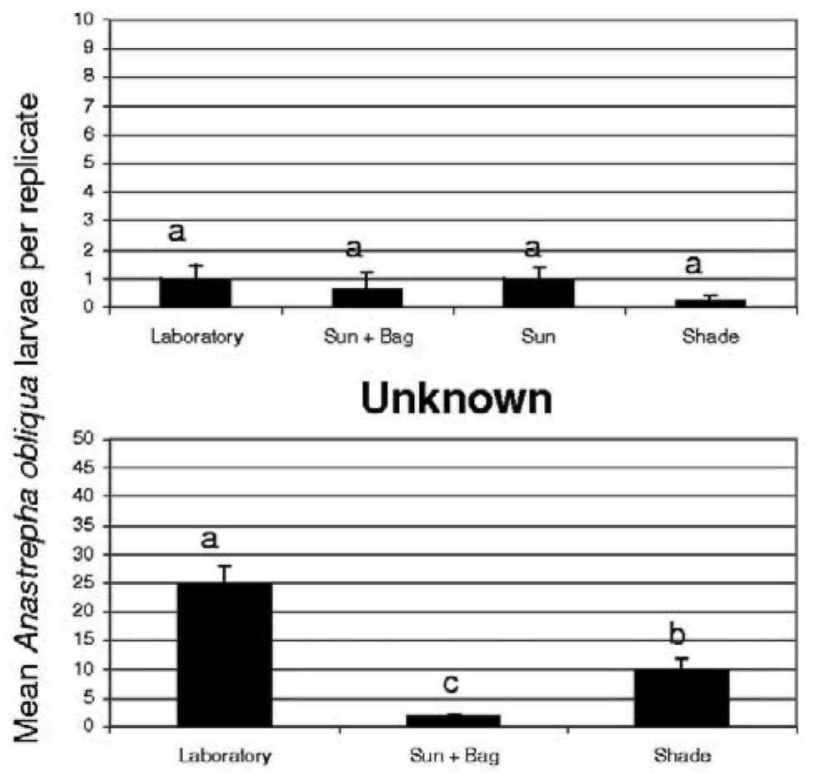

Keitt

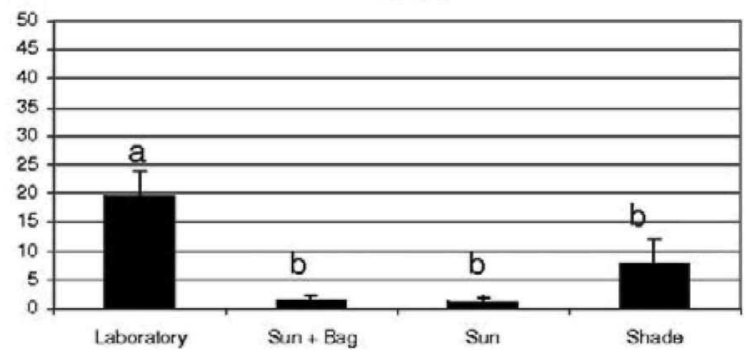

FIGURE 1. Mean number of larvae produced per replicate for assays conducted in 2005 . 


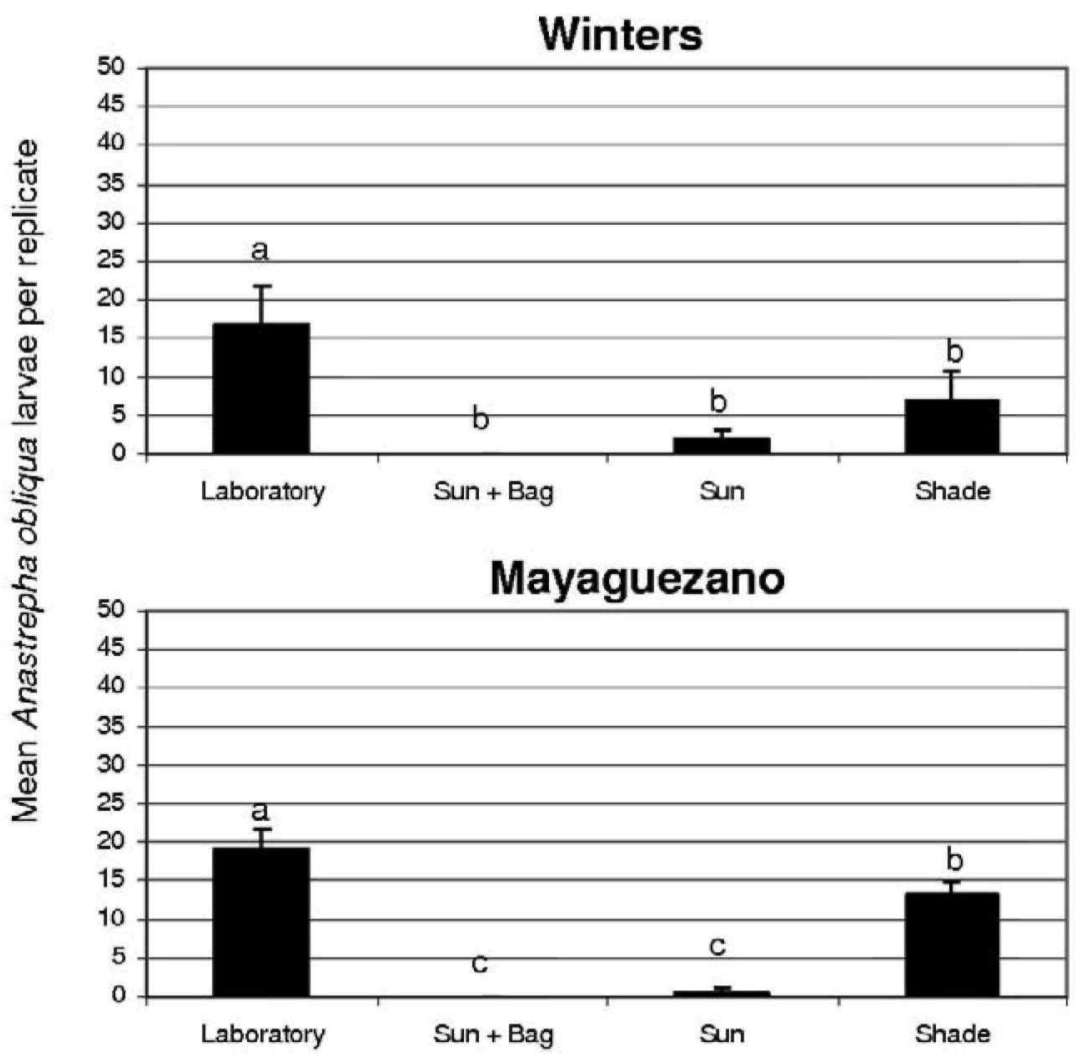

FIGURE 2. Mean number of larvae produced per replicate for assays conducted in 2006.

(Sharp and Hallman 1992). The authors noted that 99.9968\% mortality was achieved when the core of the fruit reached $44^{\circ} \mathrm{C}$. Bactrocera tryoni (Froggatt) (Diptera: Tephritidae) infesting mangoes that were exposed to vapor heat experienced $90 \%$ mortality between $39.3^{\circ} \mathrm{C}$ (second instars) and $42.8^{\circ} \mathrm{C}$ (eggs) (Heard et al., 1992). Grapefruit, Citrus paradisi MacFadyen, exposed to hot air until the core fruit temperature was $45.7^{\circ} \mathrm{C}$ resulted in probit 9 mortality of $A$. suspensa larvae within the fruit (Sharp, 1993). Immersing mangoes in hot water $\left(45.9\right.$ to $\left.46.3^{\circ} \mathrm{C}\right)$ resulted in probit 9 mortality of eggs of $A$. fraterculus (Wiedemann) when the treatment lasted $39.7 \mathrm{~min}$, and of larvae when the treatment lasted $68.5 \mathrm{~min}$ (Nascimento et al., 1992). The same treatment caused probit 9 mortality of A. obliqua eggs and larvae when the duration was 65.7 and $65.3 \mathrm{~min}$, respectively (Nascimento et al., 1992). Ceratitis cap- 


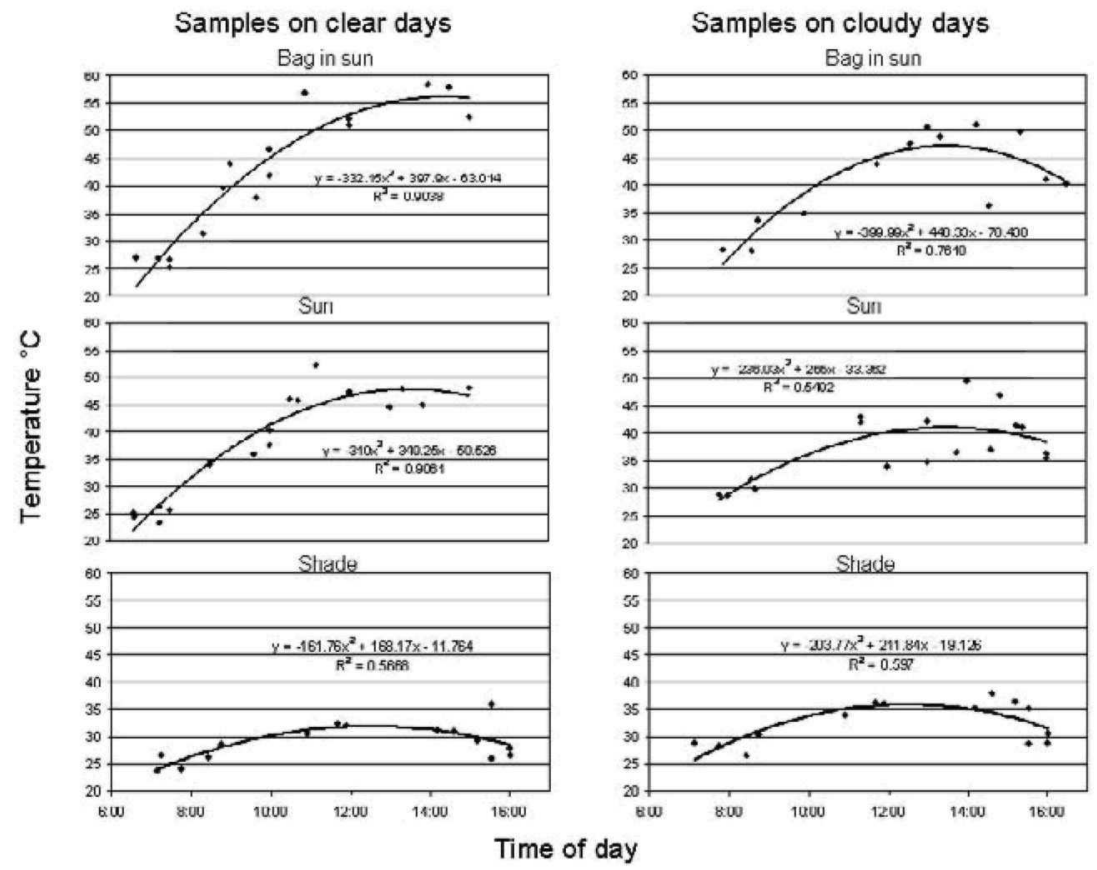

FIGURE 3. Internal temperatures of mangoes taken at various times between 0600 and 1400 hours, local time. Data points in the "clear days" column were recorded when the sun was in full view. Data points in the "cloudy days" column were recorded when the sun was obscured by clouds. Refer to the manuscript for the treatment conditions.

itata (Wiedemann) eggs and larvae experienced probit 9 mortality when the hot water immersion lasted 59.4 and $79.7 \mathrm{~min}$, respectively. Immersing guavas infested with $A$. suspensa in hot water $\left(46.1^{\circ} \mathrm{C}\right)$ for 32.7 min resulted in probit 9 mortality of the larvae (Gould and Sharp, 1992). In laboratory studies exposing third instar larvae of $A$. suspensa, no larvae survived exposure for 10 min at $47^{\circ} \mathrm{C}$ or higher temperatures (Hansen and Sharp, 1994). Longer exposure (90 or $10 \mathrm{~min}$ ) at lower temperatures ( 40 or $43^{\circ} \mathrm{C}$, respectively) resulted in increased larval mortality. Hansen and Sharp (1994) concluded that $43^{\circ} \mathrm{C}$ or above would be a suitable temperature range for the development of quarantine procedures. Interestingly, larvae reared at $30^{\circ} \mathrm{C}$ experienced lower mortality when exposed to $43^{\circ} \mathrm{C}$ than larvae that were reared at $20^{\circ} \mathrm{C}$, although rearing temperature did not affect survivorship in cold storage (Hallman, 1994). Papaya exposed to $48.5^{\circ} \mathrm{C}$ until fruit core temperature was $47.2^{\circ} \mathrm{C}(3.5 \mathrm{~h})$ resulted in probit 9 mortality of larval fruit 
flies [C. capitata, Bactrocera cucurbitae (Coquillett), and Bactrocera dorsalis (Hendel)]; shorter treatment times resulted in higher survival of fruit fly larvae, even though the fruit core temperature was $47.2^{\circ} \mathrm{C}$ (Armstrong et al., 1995).

In a very different kind of study, Kendra et al. (2007) found that composted grapefruit did pose the risk of mated female A. suspensa emerging from the fruit, although fruit fly mortality approached $100 \%$ in compost piles whose maximum internal temperature was $\geq 48^{\circ} \mathrm{C}$. In general, most studies suggest that exposure to temperatures in excess of $48^{\circ} \mathrm{C}$ for an hour seems sufficient to kill most fruit fly larvae within a fruit. In this study, fatal temperatures were reliably attained in fruit under a black plastic garbage bag in full sun and were often reached in fruit stored only in direct sun (Figure 3).

Although the placement of black plastic garbage bags around mangoes increased their internal temperature by more than $8^{\circ} \mathrm{C}$ when compared to exposed mangoes stored in full sun, this treatment rarely resulted in emergence of fewer larvae, even when compared to the number of larvae in mangoes stored in the shade. Our experiments were conducted during the rainy season, which is also mango season, and extremely high fruit temperatures $\left(50^{\circ} \mathrm{C}\right)$ were observed only on relatively rare sunny days. Precipitation, especially in the afternoon, resulted in higher convective heat loss from the fruit and occlusion of solar radiation, such that lower peak temperatures were observed. We do note that covering abscised mangoes with black plastic garbage bags more reliably increased the internal temperatures of the mangoes, even on cloudy days. Also, the bulk of mango cultivation in Puerto Rico occurs in the southern part of Puerto Rico, which is more arid and has fewer cloudy days.

The finding that the mangoes stored in the laboratory at $25^{\circ} \mathrm{C}$ almost always produced more larvae than all of the other treatments, even though mangoes stored in the shade rarely achieved temperatures higher than $35^{\circ} \mathrm{C}$, suggests that a variable aside from temperature influences mortality. We suspect that predation by other arthropods, especially by ants, and possibly by lizards, may be responsible for the observed differences, and we are currently developing experiments to test this hypothesis. It is intriguing that the Palmer cultivar produced so few flies in 2005. Whereas this cultivar was not available for continued study in 2006, we believe that it should be further investigated for possible resistance to Anastrepha spp. fruit flies.

In nature, the vast majority of abscised mangoes remain in the shade provided by their parent tree and are thus not exposed to the extreme temperatures that result from direct exposure to the sun. We suggest that removing abscised mangoes to locations where they are 
exposed to direct solar radiation, even without the facilitator of black plastic, raises the temperature sufficiently to kill a large portion of the flies. Indeed, the mortality caused by direct exposure to solar radiation far exceeds typical mortality rates caused by important parasitoids $(<1 \%)$ of Anastrepha spp. in Puerto Rico (Jenkins and Goenaga, 2008).

\section{LITERATURE CITED}

APHIS (Animal and Plant Health Inspection Service), 1985. Plant protection and quarantine treatment manual. Section VI-T106, Vapor heat, p. 24. U.S. Government Printing Office. Washington, DC.

APHIS (Animal and Plant Health Inspection Service), 1989. Plant protection and quarantine treatment manual. Section VI-T102(5), Hot water dip, pp. 9-10. U.S. Government Printing Office. Washington, DC.

Armstrong, J. W., B. K. S. Hu and S. A. Brown, 1995. Single-temperature forced hot-air quarantine treatment to control fruit flies (Diptera: Tephritidae) in papaya. J. Econ. Entomol. 88:678-682.

Denlinger, D. L., K. H. Joplin, C.-P. Chen and R. E. Lee, Jr., 1990. Cold shock and heat shock, pp. 131-148. In: R. E. Lee and D. L. Denlinger [Eds.], Insects at low temperature. Chapman and Hall, New York.

Gould, W. P. and J. L. Sharp, 1992. Hot-water immersion quarantine treatment for guavas infested with Caribbean fruit fly (Diptera: Tephritidae). J. Econ. Entomol. 85:1235-1239.

Hallman, G. J., 1994. Mortality of third instar Caribbean fruit fly (Diptera: Tephritidae) reared at three temperatures and subjected to hot water immersion or cold storage. J. Econ. Entomol. 405-408.

Hallman, G. J., R. G. McGuire, E. A. Baldwin and C. A. Campbell, 1995. Mortality of feral Caribbean fruit fly (Diptera: Tephritidae) immatures in coated guavas. J. Econ. Entomol. 88:1353-1355.

Hansen, J. D. and J. L. Sharp, 1994. Thermal death in third instars of the Caribbean fruit fly (Diptera: Tephritidae): Temperature-time relationships. J. Econ. Entomol. 87:736-740.

Heard, T. A., N. W. Heather and P. M. Peterson, 1992. Relative tolerance to vapor heat treatment of eggs and larvae of Bactrocera tryoni (Diptera: Tephritidae) in mangoes. J. Econ. Entomol. 85:461-463.

Jenkins, D. A. and R. Goenaga, 2008. Host breadth and parasitoids of fruit flies (Anastrepha spp.) (Diptera: Tephritidae) in Puerto Rico. Environ. Entomol. 37:110-120.

Kendra, P. E., M. K. Hennessey, W. S. Montgomery, E. M. Jones and N. D. Epsky, 2007. Residential composting of infested fruit: A potential pathway for spread of Anastrepha fruit flies (Diptera: Tephritidae). Florida Entomol. 90:314-320.

Mangan, R. L., and S. J. Ingle, 1992. Forced hot-air quarantine treatment for mangoes infested with West Indian fruit fly (Diptera: Tephritidae). J. Econ. Entomol. 85:1859-1864.

Nascimento, A. S., A. Malavasi, J. S. Morgante and A. L. A. Duarte, 1992. Hot-water immersion treatment for mangoes infested with Anastrepha fraterculus, A. obliqua, and Ceratitis capitata (Diptera: Tephritidae) in Brazil. J. Econ. Entomol. 85:456460.

Sharp, J. L., M. T. Ouye, W. Hart, S. Ingle, G. Hallman, W. Gould and V. Chew, 1989. Immersion of Florida mangoes in hot water as a quarantine treatment for Caribbean fruit fly (Diptera: Tephritidae). J. Econ. Entomol. 82:186-188. 
Sharp, J. L., 1992. Hot-air quarantine treatment for mango infested with Caribbean fruit fly (Diptera: Tephritidae). J. Econ. Entomol. 85:2302-2304.

Sharp, J. L., 1993. Hot-air quarantine treatment for 'Marsh' white grapefruit infested with Caribbean fruit fly (Diptera: Tephritidae). J. Econ. Entomol. 86:462-464.

Sharp, J. L. and G. J. Hallman, 1992. Hot-air quarantine treatment for carambolas infested with Caribbean fruit fly (Diptera: Tephritidae). J. Econ. Entomol. 85:168-171.

Tomasovic, S. P. and T. M. Koval, 1985. Relationship between cell survival and heatstress protein synthesis in a Drosophila cell line. Int. Radiat. Biol. 48:635-650. 